\title{
MJMR EFFECT OF COUNSELING AND MENTORING BY HEALTH WORKERS ON SUCCESS OF GIVING EXCLUSIVE BREAST MILK IN PADANG CITY
}

\author{
Binarni Suhertusi*, Fatmi Nirmala Sari \\ Lecturer of Midwifery, Midwifery of Alifah Academy Padang- Indonesia \\ Corresponding Author's Email: suhertusibinarni@yahoo.com
}

\begin{abstract}
Breast Milk contains a lot of nutrients that are very necessary for baby's growth and development and various organ development specifically. According to Indonesia Demographic and Health Survey (2015) Indonesia data, the achievement of Exclusive Breast Milk in 2015 was 55.7\%. while the coverage of exclusive breastfeeding in West Sumatra is only $75.0 \%$ (2015) of the target set by the government, which is $80 \%$. While in the city of Padang the achievement of exclusive breastfeeding was $70.5 \%$ in 2015 . The more rampant advertising of formula milk and the lack of knowledge level of mothers increasingly made the lower number of achievement of exclusive breastfeeding. The lack of support from health workers and family support (social culture) is also one of the unsuccessful mothers in providing exclusive breastfeeding. This research is a quasi-experimental design with post test only design with a control group with accidental sampling technique. It is a research that aims to determine the effect of counseling and health personnel assistance on the success of exclusive breastfeeding. The population and sample of this study were third trimester pregnant women (7-9 months of gestational age) with a sample of 16 people intervened and 16 people as controls. Data analysis was done by questionnaire using Chi Square. The results of the study showed that the respondents who were given counseling and mentoring were 14 people $(87.5 \%)$ who gave exclusive breastfeeding to their babies, while there were 3 respondents who were not given counseling and assistance. people (18.75\%) who give exclusive breastfeeding. The Chi Square test results showed that there was a significant influence between counseling and assistance with exclusive breastfeeding.
\end{abstract}

\section{Keywords: Breastmilk, Counseling, Mentoring}

\section{INTRODUCTION}

Breast milk (ASI) contains a lot of nutrients that are very necessary for baby's growth and development and various organ development specifically. Breast milk (ASI) also contains antibodies which function to protect babies against disease and death, especially because of infections that are often encountered in the first year of life (Kliegmen et al., 2007). Exclusive breast milk (ASI) is the breast milk given to babies from birth until the age of six months, without adding and or replacing it with other foods or drinks except drugs, vitamins and minerals(Roesli, 2017)

According to data from the (Kementerian Kesehatan Republik Indonesia,2018), the achievement of Exclusive breast milk (ASI) had not met the target of $80 \%$. In 2014, it was only $52.3 \%$, and a slight increase in 2015 was $55.7 \%$. While for West Sumatra in the last two years was $73.6 \%$ in 2014 and $75.0 \%$ in 2015 (Dinas Kesehatan Propinsi Sumatra Barat, 2017). In Padang city, the achievement of exclusive breat milk in the last two years was also still below the target of $72.2 \%$ in 2014 , and this achievement had decreased by
$70.5 \%$ in 2015 (Dinas Kesehatan Propinsi Sumatra Barat, 2017).

Many mothers after childbirth feel that their breast milk is not sufficient so that they need to provide additional milk by giving formula milk. In addition, the more popular of formula milk advertisinge, and the lack of mother's level of knowledg the more they make the low achievement rate of exclusive breastfeeding. The lack of support from health workers and family support (social culture) are also one of the reasons unsuccessful mothers in providing exclusive breastfeeding. The role of health workers is very important in protecting, improving, and supporting breastfeeding efforts that must be seen in terms of their broad involvement in social aspects.

Various efforts have been made for the success of exclusive breastfeeding, including the provision of counseling and assistance to breastfeeding mothers. Counseling and assistance methods are expected to improve the ability and awareness of breastfeeding mothers to provide exclusive breastfeeding. Based on 
preliminary data from 22 Puskesmas in Padang City, the lowest achievement of Exclusive Breastfeeding in 2014 was at Puskesmas Air Dingin. It was 52.6\% and in 2015 it less than $60 \%$.Based on the background above, the researcher wants to do research to determine the effect of counseling and assistance on the success of exclusive breastfeeding in Padang City.

\section{RESEARCH METHODOLOGY}

\section{Type of Research}

This research was a quasi-experimental design with post test only design with control group with accidental sampling technique. It was a research that aims to determine the effect of counseling and health personnel assistance on the success of exclusive breastfeeding.

\section{Population dan Sample \\ Population}

The population of this study were third trimester pregnant women (7-9 months of gestational age) who gave birth in Padang City.

\section{Sample}

The number of samples to be studied were 16 respondents for each group.

\section{Sampling Technique}

The sampling technique in this study was Quota Sampling

\section{Data Collection Technique}

Data was collected through data obtained from respondents using the check list table which was filled directly by health workers. The data taken were the name of the mother, age, occupation, schedule of assistance, and exclusive breastfeeding. Assistance and counseling were given 5 times, namely at the age of 7-9 months of pregnancy, at the time of delivery, and weeks 3,7 , and 11 .

\section{RESULTS}

\section{Characteristics of Respondents}

Table 1: Distribution of Respondent Frequency by Characteristics

\begin{tabular}{|l|l|l|l|l|l|l|}
\hline \multirow{2}{*}{$\begin{array}{l}\text { Character } \\
\text { istics }\end{array}$} & \multicolumn{3}{|l|}{ Group } & \multicolumn{3}{|l|}{ No assistance } \\
\cline { 2 - 7 } & \multicolumn{2}{|l|}{ assistance } & Mean & n & $\%$ & Mean \\
\cline { 2 - 7 } & n & $\%$ & & & & \\
\hline Age & & & & 2 & 12.5 & 28 \\
\hline $\begin{array}{c}<20->35 \\
\text { years old }\end{array}$ & 4 & 25 & 30 & & & \\
\hline
\end{tabular}

\begin{tabular}{|c|c|c|c|c|c|c|}
\hline $\begin{array}{l}20-35 \text { years } \\
\text { old }\end{array}$ & 12 & 75 & & 14 & 87.5 & \\
\hline $\begin{array}{l}\text { Education } \\
\text { level }\end{array}$ & & & & & & \\
\hline $\begin{array}{l}\text { D } \\
\text { III/College }\end{array}$ & 6 & 37.5 & $\begin{array}{l}\text { Senior } \\
\text { High } \\
\text { School }\end{array}$ & 4 & 25 & $\begin{array}{l}\text { Senior } \\
\text { High } \\
\text { School }\end{array}$ \\
\hline $\begin{array}{l}\text { Senior } \\
\text { High } \\
\text { school }\end{array}$ & 10 & 62.5 & & 12 & 75 & \\
\hline $\begin{array}{l}\text { Junior } \\
\text { High } \\
\text { School } \\
\end{array}$ & 0 & 0 & & 0 & 0 & \\
\hline $\begin{array}{l}\text { Occupatio } \\
\text { n }\end{array}$ & & & & & & \\
\hline $\begin{array}{l}\text { Civil } \\
\text { servant / } \\
\text { Private }\end{array}$ & 2 & 12.5 & $\begin{array}{l}\text { House } \\
\text { wife }\end{array}$ & 2 & 12.5 & \\
\hline $\begin{array}{l}\text { Entreprene } \\
\text { ur/Trader }\end{array}$ & 0 & 0 & & 1 & 6 & \\
\hline $\begin{array}{l}\text { Farmer / } \\
\text { Laborer }\end{array}$ & 0 & 0 & & 0 & 0 & \\
\hline Housewife & $\begin{array}{l}1 \\
4\end{array}$ & 87.5 & & $\begin{array}{l}1 \\
3\end{array}$ & 81.5 & \\
\hline $\begin{array}{l}\text { Frequency } \\
\text { of } \\
\text { pregnancy }\end{array}$ & & & & & & \\
\hline I & 6 & 37.5 & I & 4 & 25 & I \\
\hline II & 2 & 12.5 & & 7 & 43.75 & \\
\hline III & 5 & 31.25 & & 4 & 25 & \\
\hline IV & 2 & 12.5 & & 0 & 0 & \\
\hline $\mathrm{V}$ & - & - & & 0 & 0 & \\
\hline VI & 1 & 6.25 & & 1 & 6.25 & \\
\hline
\end{tabular}


Based on Table 1, the majority of respondents were in the age of group 20-35 years both in the intervention group and in the control group. In the intervention group, there were 12 people (75\%) and 14 people $(87.5 \%)$ in the control group. The average age in the intervention group was 30 years old and in the control group 28 years old.

The average of respondents were respondents who have high school education in both treatment groups. In the intervention group, respondents were generally more senior high school graduates, namely 10 people $(62.5 \%)$ and 12 people $(75 \%)$ in the control group.Generally, respondents as housewives were 14 people $(87.5 \%)$ in the intervention group and 13 people $(81.5 \%)$ in the control group. There were 2 people $(12.5 \%)$ respondents working as civil servants / privates in the intervention group and 2 people $(12.5 \%)$ in the control group. The average occupation of respondents in both treatment groups were as housewives.For the highest frequency of pregnancy, the first pregnancy in the intervention group was 6 people $(37.5 \%)$ while the most control group in the second pregnancy was 7 people $(43.75 \%)$.

\section{Findings}

\section{Univariate Analysis}

Univariate analysis is used to see the frequency distribution of each variable.

Table 2: Distribution of Respondents Based on Exclusive Breastfeeding in Assistance Group

\begin{tabular}{|l|l|l|}
\hline Assistance & $\boldsymbol{f}$ & $\mathbf{\%}$ \\
\hline Given & 14 & 87,5 \\
\hline Not given & 2 & 12.5 \\
\hline Total & $\mathbf{1 6}$ & $\mathbf{1 0 0}$ \\
\hline
\end{tabular}

From table 2 it could be seen that the respondents who did not provide exclusive breastfeeding in intervention group were 2 respondents (12.5\%).

Table 3: Distribution of Respondents Based on Exclusive Breastfeeding in No Assistance group

\begin{tabular}{|l|l|l|}
\hline No Assistance & $\boldsymbol{F}$ & $\mathbf{\%}$ \\
\hline Given & 3 & 18.5 \\
\hline Not given & 13 & 81.25 \\
\hline Total & $\mathbf{1 6}$ & $\mathbf{1 0 0}$ \\
\hline
\end{tabular}

From table 3 it can be seen that respondents who did not provide exclusive breastfeeding in the control group were 13 respondents $(81.25 \%)$.

Table 4: Bivariate analysis

\begin{tabular}{|c|c|c|c|c|c|c|c|c|}
\hline \multirow{3}{*}{ Assistance } & \multicolumn{4}{|c|}{ Exclusve brestfeeding } & \multirow{3}{*}{ Total } & \multirow{3}{*}{$\%$} & \multirow{3}{*}{$\begin{array}{c}P \\
\text { value }\end{array}$} & \multirow{3}{*}{ OR } \\
\hline & \multicolumn{2}{|c|}{ Given } & \multicolumn{2}{|c|}{$\begin{array}{l}\text { Not } \\
\text { Given }\end{array}$} & & & & \\
\hline & $f$ & $\%$ & $f$ & $\%$ & & & & \\
\hline Given & 14 & 87.5 & 2 & 12.5 & 16 & 100 & 0.000 & 30.333 \\
\hline Not given & 3 & 18.75 & 13 & 87.5 & 16 & 100 & & \\
\hline
\end{tabular}

Based on Table 4, it could be seen that out of 16 respondents in intervention group, there were 2 respondents $(12.5 \%)$ who did not provide exclusive breastfeeding while from 16 respondents there were 13 respondents $(81.25 \%)$ did not give exclusive breastfeeding. The results of the statistical test showed that the $p$ value was 250.25 so that it could be said that there was a significant relationship given counseling and assistance with exclusive breastfeeding. The effect of the act of giving counseling and assistance on exclusive breastfeeding was that the respondents who were given counseling and assistance actions had 30.333 times greater chance of giving exclusive breastfeeding to their babies than respondents who were not given counseling and assistance.

\section{DISCUSSION}

\section{Exclusive brestfeeding(ASI) \\ Exclusive breastfeeding for mentoring groups}

From table 2 it could be seen that respondents who did not give exclusive breastfeeding to the group who were given counseling and assistance were 2 respondents $(12.5 \%)$.

One of the goals of providing counseling and assistance according to was the service of assistance by professionals to individuals or groups of individual for the development of effective daily life which was interrupted by an independent focus that was able to control themselves through the implementation of various types of services and activities supporter (Syafaruddin, 2017).

The researcher assumed that there were still mothers who did not give exclusive breastfeeding to their babies 
while having been given counseling and assistance. It was because the mothers were less confident that their breast milk were not enough for their baby plus the influence of parents and parents in laws. In this study, mothers who did not provide exclusive breastfeeding were found in mothers with first children.

\section{Giving Exclusive ASI to No Assistance Groups}

From table 3 it could be seen that respondents who did not provide exclusive breastfeeding to the group who were not given counseling and assistance were 13 respondents $(81.25 \%)$.

Assistance was the process of guiding or giving opportunities to the community, especially the poor, which was carried out by assistances or facilitators through a series of activities that enable the community to have the ability and confidence in dealing with problems around their lives.

The researcher assumed that mothers who did not give exclusive breastfeeding because of the lack of family role and the level of the mothers' knowledge about the benefits and ways of giving exclusive breastfeeding.

\section{Counseling and Assistance with Exclusive Breast feeding}

Based on Table 4 it could be seen that out of 16 respondents who were given counseling and mentoring, there were 2 respondents $(12.5 \%)$ who did not provide exclusive breastfeeding while from 16 respondents who were not given counseling and assistance there were 13 respondents $(81.25 \%)$ were not giving breatfeeding Exclusive. In the results of the statistical test obtained $p$ value value 0.25 so that it can be said that there was a significant relationship between assistance and exclusive breastfeeding.

This was appropriate with previous research on the role of health workers in the success of exclusive breastfeeding where the health workers had a positive impact on breastfeeding mothers by providing counseling about exclusive breastfeeding and counseling on Early Breastfeeding Initiation (IMD). All respondents succeeded in exclusive breastfeeding for infants aged 6-12 months(Sabati, 2015).

Another research related to exclusive breastfeeding was health promotion using leaflet and film media, where there was a significant influence on the knowledge of pregnant women about exclusive breastfeeding given health promotion using leaflets and film media (Suhertusi, Desmiwarti \& Nurjasmi, 2015). A study concluded that there was an influence of counseling on the level of knowledge and attitudes of breastfeeding mothers in exclusive breastfeeding in Kanigoro District, Blitar Regency(Syahputri, 2018).

The researcher assumed that providing counseling and assistance to mothers starting from pregnancy, childbirth to children the age of 6 months was very necessary because of the low level of mothers' knowledge and the incessant advertising about formula milk. The role of the family also greatly influenced the success of mothers in exclusive breastfeeding where there were still many families who doubted the insufficiency of breastfeeding for their babies.

\section{CONCLUSION}

The success of mothers giving exclusive breastfeeding to infants with respondents who have been conducted counseling and assistance interventions turns out to be more.The success of mothers giving exclusive breastfeeding to infants with respondents who are not carried out by counseling and assistance interventions are less.There is a significant difference, namely the group given the counseling intervention and assistance had 30.333 times greater chance of giving exclusive breastfeeding to their babies compared to the control group of respondents who are not given counseling and assistance.

\section{SUGGESTION}

It is expected that the health center staff, health workers and independent practice midwives will be able to apply counseling and assistance to the mothers about exclusive breastfeeding starting from pregnancy, childbirth to the age of 6 months.

\section{REFERENCES}

Dinas Kesehatan Propinsi Sumatra Barat. (2017). Profil Dinas Kesehatan Tahun 2017. Retrieved from:http://www.depkes.go.id/resources/download /profil/PROFIL_KES_PROVINSI_2017/03_Sum bar_2017.pdf

Kementerian Kesehatan Republik Indonesia. (2018). Profile Kesehatan Indonesia Tahun 2017. Retrieved 
from:http://www.depkes.go.id/resources/download/pu sdatin/profil-kesehatan-indonesia/Profil-KesehatanIndonesia-tahun-2017.pdf

KLiegmen, R., Behrman, R., Jenson, H. \& Stanton, B. (2007). Nelson Textbook of Pediatrics. Saunders, U.S

Roesli, U.(2008). Guidance of EIB plus exclusive breastfeeding, first edition, Pustaka Bunda, Jakarta. Retrieved from: https: //www.iaescore.com/ journals / index.php/IJPHS/article/viewFile/4732/3756

Sabati, M. R. (2015). Peran Petugas Kesehatan terhadap Keberhasilan Pemberian ASI Eksklusif : Studi Kualitatif di Wilayah Puskesmas Sekaran Kecamatan Gunungpati Kota Semarang (tidak dipublikasi). Universitas Diponegoro.Retrieved from: http://eprints.undip.ac.id/47097/1/763_Maryasti
Rambu_Sabati.pdf.

Suhertusi, B., Desmiwarti .\& Nurjasmi, E. (2015). Pengaruh Media Promosi Kesehatan tentang ASI Eksklusif terhadap Peningkatan Pengetahuan Ibu di Wilayah Kerja Puskesmas Lubuk Begalung Padang Tahun 2014. Jurnal Kesehatan Andalas, 4(1pp), $17-22$.

Syafaruddin. (2017). Bimbingan \& Konseling. (A. S. Syafaruddin, Ahmad Syukri Sitorus, Ed.) (1st ed.). Sumatera Utara: Perdana.

Syahputri, R. B. (2018). Peran Petugas Puskesmas Dalam Sosialiasasi, Edukasi, Dan Kampanye Untuk Meningkatkan Cakupan ASI Eksklusif Di Wilayah Kerja Puskesmas Gilingan Surakarta. Retrieved from: http://eprints.ums.ac.id/61308/11/11. NASPUB.pdf 